\title{
PERKEMBANGAN KALIGRAFI DAN URGENSINYA BAGI KHAZANAH MUSHAF
}

\section{THE DEVELOPMENT OF ISLAMIC CALLIGRAPHY AND ITS URGENCY FOR THE QUR'ANIC MANUSCRIPTS}

\author{
Abdul Hakim \\ Universitas Islam Negeri Syarif Hidayatullah, \\ Jakarta, Indonesia \\ hakimsyukrie@gmail.com
}

DOI: $10.31291 /$ jlk.v19i1.911

Diterima: 10 Maret 2021; Direvisi: 16 Juni 2021; Diterbitkan: 30 Juni 2021

\begin{abstract}
This article is an analysis of the book Khat al-Muṣhaf al-Syarif wa Tatawwuruhu fi al- 'Ālam al-Islāmī by Abdul Aziz Hamid Saleh. This book elaborates the science of calligraphy with a study of the history of the Qur'anic manuscripts in the Islamic world. It also contains a historical review of the development of calligraphy manuscripts based on Islamic cultural areas in the Hijaz, Sham, Iraq, Egypt, Andalus, India, and Far Asia. The steps taken in reviewing this book are summarizing and reviewing it. This paper shows that a manuscript of the Qur'an can be revealed in its history based on the khat used. Therefore, calligraphy is an alternative method for studying the history of the Qur'anic manuscripts other than through the study of colophons, paper types, decorations, and carbon testing.
\end{abstract}

Keywords: Islamic Calligraphy, Mushaf Al-Qur'an, Islamic Art

\section{ABSTRAK}

Artikel ini merupakan analisis atas buku Khat al-Mușhaf al-Syarīf wa Tatawwuruhu fi al- 'Ālam al-Islāmī karya Abdul Aziz Hamid Saleh. Buku ini mengelaborasi ilmu kaligrafi dengan kajian sejarah mushaf al-Qur'an di dunia Islam. Di dalamnya juga terdapat ulasan sejarah perkembangan kaligrafi mushaf berbasis wilayah kebudayaan Islam di Hijaz, Syam, Iraq, Mesir, Andalus, India, dan Asia Jauh. Langkah yang dilakukan dalam mengkaji buku ini, yaitu meringkas dan menelaahnya. Tulisan ini menunjukkan bahwa sebuah mushaf Al-Qur'an dapat diungkap sejarahnya berdasarkan khat yang digunakan. Oleh sebab itu, Kaligrafi menjadi 
metode alternatif untuk menelaah sejarah mushaf Al-Qur'an selain melalui telaah kolofon, jenis kertas, ragam hias, dan uji karbon.

Kata Kunci: Kaligrafi Islam, Mushaf Al-Qur’an, Seni Islam

\section{PENDAHULUAN}

Pada tahun 1972 sejumlah pekerja proyek renovasi Masjid Jāmi' Șan'à Yaman menemukan sejumlah mushaf ${ }^{1}$ dan ribuan lembar perkamen berisi ayat Al-Qur'an. Mereka memasukkan barang-barang tersebut dalam 20 wadah dan meletakkan begitu saja di bawah tangga masjid. Sepuluh tahun kemudian bendabenda tersebut ditemukan ulang oleh Qādī Ismā'îl al-Akū' (Ketua Lembaga Warisan Budaya Yaman). Setelah dihitung, lembaran tersebut berjumlah 40.000 lembar 15.000 di antaranya lembaran kertas kulit. Jumlah tersebut setelah diklasifikasi, merupakan bagian tercecer dari 940 mushaf. Hal itu belum termasuk jumlah mushaf yang ditemukan utuh. Di antara jumlah tersebut sebanyak 20-25 mushaf ditulis dengan khat Kufi, dan sedikit berkhat Hijaz. ${ }^{2}$

Berdasarkan uji karbon 14 (radiocarbon dating) terhadap bahan mushaf, ditemukan angka tahun 542-643 M. Tahun 643 bertepatan dengan tahun $23 \mathrm{H}$, masa terakhir Khalifah Umar bin Khattab. Jika diambil titik tengah dari angka tersebut, maka didapati angka tahun 592,5 M yaitu berdekatan dengan tahun kelahiran Nabi Saw. ${ }^{3}$ Untuk itu, hasil uji karbon ini tidak bisa diterima oleh beberapa kalangan sarjana Al-Qur'an seperti Qadduri dan Mehmet Cebi, baik tahun terdekat maupun terjauh,

${ }^{1}$ Artikel ini kadang menggunakan kata mushaf atau Al-Qur'an, tergantung konteks kalimat. Kata mushaf digunakan untuk wujud fisik AlQur'an. Sedangkan kata 'Al-Qur'an' digunakan untuk kandungan Al-Qur'an.

${ }^{2}$ François Déroche, Qur'ans of the Umayyads: A First Overview, ed. Léon Buskens (Leiden: Brill, 2014), 13; A Rippin, "Qur'ans of the Umayyads," American Journal of Islam and Society 32, no. 4 (2015): 114-117.

${ }^{3}$ Behnam dan Mohsen Goudarzi Sadeghi, "Sana'a 1 and The Origins of The Qur'an," Der Islam 87, no. 1-2 (2012): 1-129; Rippin, "Qur'ans of the Umayyads." 
karena bertentangan dengan banyak sumber sejarah Islam khususnya sejarah penulisan Al-Qur'an. ${ }^{4}$

Pada tahun 2015, Universitas Birmingham merilis kajian mushaf tua yang tersimpan di perpustakaannya. Mushaf tersebut disalin di kertas kulit dengan khat Hijazi. Menurutnya, setelah melalui uji karbon, lembaran-lembaran mushaf tersebut berasal dari tahun antara 568-645 M dengan toleransi kesalahan 5\%. Tahun $568 \mathrm{M}$ sama dengan beberapa tahun sebelum kenabian Muhammad saw. ${ }^{5}$ Tahun $645 \mathrm{H}$ bertepatan tahun 24 Hijriah yaitu awal masa Khalifah Usman (24-35 H). Jika diambil nilai tengahnya yaitu tahun $606 \mathrm{M}$, maka itu bertepatan tahun 14 sebelum Hijriah. Jika tetap berpegang pada angka tahun tersebut, maka mushaf ini disalin jauh sebelum masa Usman bin Affan. David Thomas, peneliti dari Universitas Birmingham, bersikukuh dengan memberikan argumen bahwa bisa saja para sahabat sebelum Khalifah Usman sudah menulis perkamen ini langsung dari Rasulullah. ${ }^{6}$

Klaim di atas bertolak belakang dengan fakta bahwa penulisan wahyu dilakukan dengan sistem ayat yang terpisah-pisah. Penulisan wahyu kadang satu ayat atau beberapa ayat dan tidak dalam satu surah utuh kecuali saat dilakukan pengumpulan mushaf kedua pada zaman Khalifah Usman bin Affan. ${ }^{7}$ Susunan ayat mushaf Birmingham sudah tersusun rapi dari surah Maryam hingga awal surah Taha berdasarkan kaidah kompilasi Usman bin Affan. Selain itu, dari analisis tanda baca mushaf ini juga sudah menggunakan tanda i'rāb metode Abu al-Aswad al-Du'ali (w. $67 \mathrm{H})$ yang mulai berlaku pertengahan abad ke-1 Hijriah.

${ }^{4}$ Abdu al-Azīz Hamīd Șālị̣, Khaț Al-Muṣhaf Al-Sharīf Wa Tațawwaruhu F̄̄ Al- 'Ālam Al-Islāmī (Beirut: Dār al-Kutub al-Ilmiyyah, 2020), 94.

${ }^{5}$ Nur Faizin, "Keraguan Seputar Mushaf Al-Qur'an: Kajian Resepsi Terhadap Manuskrip Birmingham," SUHUF 9, no. 2 (2017): 215-40.

${ }^{6}$ Yasin Dutton, "Two 'Hijāzī' Fragments of the Qur' an and Their Variants, or: When Did the Shawādhdh Become Shādhdh?," Journal of Islamic Manuscripts 8, no. (2017): 1-56; Nur Faizin, "Keraguan Seputar Mushaf Al-Qur'an: Kajian Resepsi Terhadap Manuskrip Birmingham," SUHUF 9, no. 2 (August 16, 2017): 215-40, https://doi.org/10.22548/ shf.v9i2.241.

${ }^{7}$ Muhammad Țāhir bin 'Abdul Qādir al-Kurdi, Tārīkh Al-Qur'ān Wa Gharā'ibu Rasmihi Wa Hukmuhu (Jeddah: al-Fatḥ, 1946), 41. 
Berdasarkan sumber sejarah, mushaf yang ditulis pada zaman Usman tidak menggunakan tanda harakat dan titik. Berdasar kasus ini, mungkin perlu dipertimbangkan metode baru lainnya yang membantu penentuan angka tahun sebuah mushaf. ${ }^{8}$

Dua peristiwa di atas mewarnai diskursus studi Al-Qur'an khususnya permushafan dalam setengah abad terakhir. AlQur'an sejak diwahyukan, ditulis, disalin, dan dikompilasi sudah diproduksi dalam bentuk mushaf dari zaman ke zaman. Kajian atas kandungannya melahirkan ilmu baru dan hasil penelitian yang beragam dengan karya mulai buku tipis hingga berjilidjilid. Fisiknya juga tidak lepas dari kajian yang dilakukan baik muslim maupun nonmuslim, bisa ataupun tidak bisa baca AlQur'an. Kajian Al-Qur'an, utamanya, lebih banyak dilakukan dari disiplin ilmu-ilmu Qur'an: Tafsīr, Asbāb al-Nuzul, MakkiMadani, Waqfu wa al-ibtidā' dan lain-lainnya. ${ }^{9}$ Kajian menggunakan pendekatan ilmu-ilmu Al-Qur'an biasanya terkait dengan kandungan Al-Qur'an. Adapun terkait materialnya, biasanya digunakan ilmu bantu lain seperti kodikologi dan epigrafi. Buku yang akan diulas ini mengetengahkan kajian mushaf menggunakan ilmu bantu khat/kaligrafi sebagai pisau analisisnya.

Buku yang dikaji memiliki tebal 541 halaman berjudul Khat al-Muṣhaf al-Syarīf wa Tațawwuruhu fi al- 'Ālam al-Islāmī. Ditulis oleh Abdul Aziz Hamid Saleh dan diterbitkan oleh Dār al-Kutub al-'Ilmiyyah tahun 2020. Tahapan kajian dalam tulisan ini diawali dengan meringkas bab per bab yang terdapat dalam buku tersebut, selanjutnya penulis berupaya memberikan telaah pengembangan isi buku tersebut dalam konteks kekinian.

${ }^{8} \mathrm{Uji}$ carbon 14 (radiocarbon dating) hanya untuk menguji bahan kertas, bukan untuk uji tulisan. Tahun yang dihasilkan dari uji tersebut merujuk pada tahun binatang disembelih (kalau kertas kulit). Dan tidak ada metode yang bisa menentukan berapa lama dari tahun disembelih hingga kertas tersebut dipakai. Kulit yang hendak dipakai untuk menulis membutuhkan waktu panjang untuk prosesnya, terutama dari baunya. Kertas kulit tersebut bisa juga didatangkan dari tempat yang jauh lewat perdagangan. Proses demikian membutuhkan waktu bertahun-tahun.

${ }^{9}$ Abdul Hakim, "Metode Kajian Rasm, Qiraat, Wakaf Dan Dabt Pada Mushaf Kuno (Sebuah Pengantar)," SUHUF 11, no. 1 (August 24, 2018): 7792. 
Buku ini terbagi dalam sebelas bab pembahasan. Kajian kaligrafi ${ }^{10}$ mushaf buku ini dimulai dengan bahasan mushaf AlQur'an generasi awal. Setelah itu, masuk kepada kajian mushaf berdasarkan wilayah dunia Islam: mushaf Hijaz, mushaf Syam, mushaf Iraq, mushaf Mesir, mushaf Magrib dan Andalus, Asia Tengah, Anatolia (Turki), India, Asia Dekat meliputi Asia Tenggara dan Cina. Pembahasan wilayah geografis mushaf ini terlihat jelas menggunakan istilah wilayah keislaman lama. Jika daulah Islam pernah ada di satu wilayah, maka dibahas pula kaligrafi mushafnya pada buku ini. Uniknya, buku ini menyertakan pembahasan mushaf yang ada di wilayah Asia Dekat yang meliputi Cina dan Asia Tenggara. Wilayah terakhir ini jarang sekali diikutsertakan dalam kajian Islam global bertemakan sejarah khazanah Islam. Selain terkesan jauh dari Islam 'pusat' (Timur Tengah) juga dianggap tidak memiliki rekam sejarah daulah Islamiyah di kancah global masa lalu. ${ }^{11}$

\section{HASIL DAN PEMBAHASAN}

\section{Mushaf Generasi Awal: dari Hijaz ke Syam}

Maksud dari mushaf Hijaz adalah mushaf yang disalin pada zaman Khalifah Rasyidin dan atau mushaf yang disalin menggunakan khat Hijaz. Khat ini yang digunakan untuk menyalin mushaf-mushaf pada periode Islam Madinah. Ibnu Nadīm (w. $438 \mathrm{H}$ ) mengatakan ada dua gaya khat di Madinah saat itu: khat Mekkah dan khat Madinah. Khat Mekkah lebih tua dari khat Madinah. Ia berasal dari Mekah Utara dari Hirah kemudian menyebar ke wilayah Hijaz. Ciri-ciri khat Hijaz atau khat Mekah Utara yaitu huruf alif, lam, ța' dan da lebih tinggi dari ukuran biasa dan condong kanan (slant-script), ukuran huruf yang tipis, gigi huruf lebih pendek/kecil. Ibnu Muqlah (w. 328 H) mengata-

\footnotetext{
${ }^{10}$ Pada artikel ini, kadang menggunakan kata kaligrafi, khat atau gaya tergantung konteks masing-masing.

${ }^{11}$ Azyumardi Azra, "Islam Indonesia: Kontribusi Pada Peradaban Global," Prisma 29, no. 4 (2010): 83-91; Faris Maulana Akbar, "Peranan Dan Kontribusi Islam Indonesia Pada Peradaban Global," JURNAL INDOISLAMIKA 10, no. 1 (2020): 51-63, https://doi.org/10.15408/idi.v10i1.17522.
} 
kan itu dengan sebutan khat perkamen: jenis khat kaku yang tidak memiliki garis lengkung. ${ }^{12}$

Berdasarkan kajian yang ada, hingga saat ini belum ditemukan mushaf yang dipastikan salinan dari zaman Khalifah Rasyidin baik mushaf lengkap atau lembarannya. Hal itu bisa terjadi karena termakan usia, binatang pemakan kertas, atau dibakar. Kasus terakhir terkait dengan akhlaq tidak boleh membiarkan lembaran kalam mulia tercecer begitu saja, sehingga dimusnahkan sebagai bentuk pemuliaan. Ada beberapa temuan penting terkait mushaf atau bagian mushaf yang ditulis menggunakan khat jenis ini, namun jumlahnya sedikit. Di antara yang sedikit tersebut tersimpan dan ditemukan di British Library London, Masjid 'Amr bin 'Āṣh, Perpustakaan Universitas Birmingham, dan perpustakaan Masjid Șan'ā' Yaman. ${ }^{13}$

Perkembangan mushaf dan kaligrafinya kemudian merambah ke wilayah Syam. Mushaf Syam tersebar baik di Syam maupun negeri lainnya. Perkembangan produksi mushaf sangat masif utamanya pada zaman khalifah Abdul Malik bin Marwan. Beberapa nama penyalin mushaf pada dinasti Umayyah yaitu Khālid bin Abi Hayyāj. Ia pernah diminta Umar bin Abdul Aziz menulis mushaf. Selain menulis mushaf, al-Hayyāj juga menulis inskripsi pada bangunan monumen salah satunya di Masjid Nabawi. Sayangnya, tidak ada satupun mushafnya yang sampai ke zaman sekarang, meskipun Ibnu Ishāa pernah menyaksikannya saat ia hidup. Sebagai catatan, menyalin mushaf mulai abad ke-2 Hijriah sudah menjadi profesi yang menjanjikan. Kaligrafer lainnya, Malik bin Dinar. Selain cakap menyalin, ia juga hafal Al-Qur'an. Ia menyalin Al-Qur'an untuk dijual kepada masyarakat yang membutuhkan. Imam al-Dānī (w. 444 H) ketika melakukan eksplorasi naskah Al-Qur'an menemukan mushaf yang disalin al-Mugīrah bin Mina pada bulan Rajab tahun $110 \mathrm{H}$. Beberapa lembaran suhuf yang diklaim berasal dari daulah Umayyah tersebar di beberapa lembaga: Museum Metropolitan New York, Universitas Harvard, Museum Kuwait, Masjid San'ā'

12 Șālih, Khaṭ Al-Muṣhaf Al-Sharīf Wa Tațawwaruhu F̄̄ Al-'Ālam AlIstāmī, 95-96.

${ }^{13}$ Șāliḥ, 79. 
Yaman, perpustakaan Imam Ridha di Masyhad Iran, dan kotakota lainnya. ${ }^{14}$

Mulai pertengahan masa Abbasiyyah mushaf Syam ditulis pada bahan kertas katun (papers), tidak lagi dijumpai mushaf berbahan kulit binatang. Mushaf yang tertua dari kota ini berangka tahun 563 H/1167 salinan Ja'far bin As'ad al-Kātib. Dikenal juga dengan mushaf Sultan Nuruddin Zanki (541-569 H/1146$1173 \mathrm{M}$ ): khat naskhi, nama surah berkhat kufi mutatawwar dan ragam hias sulur bunga. ${ }^{15}$ Khat naskhi mulai berkembang di Syam pada awal abad ke-6 H. Meskipun sama, tapi naskhi Suriah berbeda karakter dengan naskhi daerah lainnya. Biasanya disebut juga dengan naskhi Suriah, cenderung ke khat Sulus. Pembawanya yaitu Amir Sinjar (Qutubuddīn Sinjār). Ia yang mewarnai penulisan mushaf dengan khat naskhi Suriah.

Panyalin lainnya yaitu Gāzī bin Abdurahman (abad ke-8 H, khat mansub), dan Najmuddīn Musa bin 'Ali bin al-Bașị̄ (w. 716 H/1316), Muhammad bin al-Wahīd (w. 711 H), Aḥmad bin Abī Ibrahīm bin Muhammad al-Syāfi'i al-Quraysīîn ${ }^{16}$, Ibrahīm bin Ali bin Șāni' al-Malik, Kamaluddīn 'Umar bin Ạ̣mad alias Ibnu al-'Adīm (w. $660 \mathrm{H}),{ }^{17}$ Kamaluddīn Aḥmad bin 'Abd al-Azīz alHalabi alias Ibnu al-‘Ajmi (w. 666 H), Imaduddin Muhammad bin Hibatullāh al-Syirajī al-Dimasyqi, Muhammad bin Naj̄̄b alAkhlațī (w. $726 \mathrm{H} / 1325 \mathrm{M}$ ), Burhanuddin Hawami (w. 732 H/1332 M). Pada masa Ilkhanat ada Muhammad bin Asīd alNajjār alias Ibnu al-Akhlațī (w. 726 H/1325 M). Tidak sedikit dari mereka yang kemudian mengembangkan khat di Mesir, mukim dan wafat di sana. Setelah invasi Timurleng, Syam masih

${ }^{14}$ Șāliḥ, 126.

${ }^{15}$ Tersimpan di Kier Collection di Skotlandia. Panyalin lainnya yaitu Gāzì bin Abdurahman (abad ke-8 H) dengan khat mansub, dan Najmuddin Musa bin Ali bin al-Bașīṣ (w. 716 H/1316)

${ }^{16}$ Mushaf salinannya tersimpan di Museum Topkapi berangka tahun $741 \mathrm{H} / 1341 \mathrm{M}$. berkhat naskhi dengan tinta emas. Tanda surah berkhat sulus tinta putih dengan latar warna biru bersulur dedaunan.

${ }^{17}$ Dikenal sebagai kaligrafer sekaligus penghias mushaf dan juga sejarawan. Bukunya berjudul 'Sejarah Homs' 
tetap melahirkan para penyalin mushaf handal antara lain Syarafuddīn bin al-Amīr.

Pada awal abad ke-20 ada nama Muhammad Husni alBābā murid kaligrafer Turki Yūsūf Rasyā yang hijrah ke Mesir tahun 1912. Ia adalah penulis khat pada kiswah ka'bah. Ia merupakan guru dari Muhammad Ali Makāwī dan Hāsyim alBagdādī (Iraq). Periode berikutnya adalah Usman bin 'Abduh bin Ṭāhā al-Halabi alias Syaikh Usmān Țāhā, seorang imam dan khatib salah satu masjid di Homs. Ia belajar khat pada ayahnya, khat Ta'liq dari Muhammad Badawī al-Dīrān̄̄ dan mengambil ijazah khat dari Hāsyim al-Bagdādī (sulus dan naskhi) dan Ḥāmid al-Āmidī. Di tangan Usmān Tāhā, khat naskhi mushaf menjadi istimewa karena: pertama memperjelas posisi huruf sehingga tidak saling tumpuk dan serta memperjelas huruf yang terlihat sama seperti ha' dan mim. Kedua, membagi huruf setiap baris dengan rapi tanpa ada yang berdesakan. Ketiga, setiap baris pada tiap halaman berakhir pada akhir ayat. Ia menulis dengan khat naskhi sebanyak 13 mushaf dan semuanya dicetak. Ia juga menuliskan lafal jalalah dengan tinta berbeda: tinta merah. Kebanyakan mushaf yang dicetak di dunia Islam masa kini menggunakan master mushaf miliknya. ${ }^{19}$

Menurut Aziz, berdasar eksplorasi dan analisis khat, tidak ada satu mushaf maupun satu lembaran dari mushaf masa awal yang dapat dipastikan berasal dari Syam masa Umayyah. Klaim mushaf dari dinasti umayyah biasanya bukan mushaf dari Syam tetapi dari Iraq (ditulis masa Umayyah). Sebuah mushaf berukuran besar di Musuem Metropolitan New York berukuran 33,7 x 50,8 cm diyakini berasal dari Syam. Mushaf ini mengunakan khat sulus dan nama surah berkhat kufi Mutatawwar. Disalin di kota Damaskus masa sultan Najmuddīn Ayyūb (635-637 H). ${ }^{20}$

${ }^{18}$ Șāliḥ, Khaṭ Al-Muṣhaf Al-Sharīf Wa Tațawwaruhu F̄̄ Al-'Ālam AlIslāmī, 145-48.

${ }^{19}$ Șāliḥ, 149. 


\section{Iraq: Gudang Penyalin Mushaf Dunia Islam}

Produksi mushaf Iraq sudah dimulai dari pertengahan masa daulah Umayyah dan mengalami perkembangan pesat masa daulah Abbasiyah. Dua nama generasi awal penulis mushaf dari Iraq yaitu Mahdi al-Kūfī dan Khusynam al-Bașri. Keduanya berkarya hingga akhir abad ke $2 \mathrm{H} / 9 \mathrm{M}$, kemudian pindah ke Ibu kota baru (Baghdad) yang berdiri pada $145 \mathrm{H}$. Saat itu khat yang digunakan secara umum dalam penulisan mushaf disebut dengan khat kufi mushaf. Penggunaannya berlangsung hingga akhir abad ke-3 H/9 M.

Tinggalan mushaf yang ada hingga sekarang adalah sebuah mushaf berukuran besar yang konon ditulis oleh Ali bin Abi Talib dan tersimpan di Masjid Husain di Kairo. Mushaf ini pernah disebutkan juga oleh Ibnu Bațuttah (w. 1369 M) dalam risalah perjalanannya pada Sya'ban 726 H/1325 M. Ibnu Bațūṭah melihat mushaf ini di ribat Tajuddin, bukan di Masjid Husain. Ini memperkuat catatan Ibnu Jubair (w. $614 \mathrm{H}$ ) yang satu setengah abad sebelumnya melakukan perjalanan ke Masjid Husain dan tidak menyebutkan ada mushaf Ali maupun mushaf lainnya. ${ }^{21}$ Menurut catatan Ibnu Bațūtah, pemilik naskah membelinya seharga 100.000 dirham. $^{22}$ Penisbatan mushaf ini pada Ali bin Abi Talib dapat dibantah. Pertama, bahwa Ali bin Abi Talib tidak pernah diriwayatkan menulis Al-Qur'an secara lengkap dalam satu media kertas kulit dengan susunan yang sudah rapi. Bahwa Ali bin Abi Talib menulis Al-Qur'an, betul adanya, tetapi belum sistematik. Kedua, adanya tanda titik (hitam) dan irāb (merah) serta khat yang digunakan, ${ }^{23}$ diperkirakan mushaf tersebut berasal dari masa tidak lebih dari paruh kedua masa daulah Umayyah. ${ }^{24}$ Ditulis dengan khat yābis (kaku) dengan beberapa huruf dipanjangkan.

\footnotetext{
${ }^{21}$ Muhammad bin Ahmad Ibnu Jubair, I'tibā al-Nāsik fì Zikri al-Āsārr al-Karīmah wa al-Manāsik (Beirut: Dār wa Maktabah al-Hilāl, 1986), 217.

${ }^{22}$ Ibnu Bațūtah, Tuhfah an-Nadhār fì Garā'ib al-Amșār Wa 'Ājā'Ib alAsfār (Beirut, 1985), 64.

${ }^{23}$ Tanda baca garapan Abu al-Aswad al-Du'ali (w. 67 H.).

${ }^{24}$ Diduga kuat naskah ini dibuat di Iraq (Kufah) pada masa gubernur Hajjaj bin Yūsūf al-Śaqafi (w. 95 H/714 M) yang dikirimnya ke Abdul Aziz bin Marwan (w.85 H/704 M) selaku Gubernur Mesir pada masa Khalifah
} 
Perkembangan jenis khat dalam penulisan mushaf berkembang pesat di wilayah Iraq. Istilah yang digunakan antara lain khat kufi mushaf, kufi kecil, kufi besar, kufi Abbasi, dan lainnya. Kufi kecil adalah jenis khat kufi yang digunakan menulis kitab termasuk Al-Qur'an. Sedangkan kufi besar adalah jenis khat yang digunakan menulis prasasti, monumen, atau bangunan. Khat jenis ini biasanya disebut juga dengan Monumental Kufic. Pengertian lainnya, jika gaya kufi besar digunakan untuk menulis mushaf, maka jumlah barisnya 3-5 baris per halaman. Jika jumlah barisnya lebih dari itu, 15-16 baris perhalaman, maka disebut kufi kecil. Sebutan lainnya adalah kufi mushaf. Jenis kufi ini merupakan sebutan umum untuk khat kufi pada periode awal penulisan mushaf hingga mengalami perkembangan khat kufi di Iraq. Jenis kufi ini terus berkembang mulai akhir abad ke-3 Hijriah hingga pertengahan abad ke-4 hijriah. Dari namanya, khat jenis ini diperuntukkkan penyalinan mushaf. Bahan yang digunakan adalah kertas kulit (perkamen). Berdasarkan tinggalan yang ada, tidak ada jenis khat ini yang ditulis di atas kertas papirus (al-qirtās al-bardi) ataupun kertas katun.

Penggunaan khat kufi mushaf pada penyalinan Al-Qur'an mulai bergeser seiring munculnya nama Abu Ali Muhammad bin Ali bin Hasan. Ia Lahir di Baghdad tahun 272 H/885 M dan meninggal di kota yang sama tahun (w. 328 H/939 M). Dikenal juga dengan nama Ibnu Muqlah. Ia memperkenalkan kaidah baru dalam penulisan huruf Arab yang menjadi babakan baru dalam penyalinan mushaf di dunia Islam. Ibnu Muqlah mempelopori khat layyinah (lentur), sebagai antitesa khat yābis (kaku). Khatnya disebut juga khat al-Mansūb. Berdasar sumber sejarah, Ibnu Muqlah (w. 328 H/939 M) hanya menulis dua mushaf. Beberapa lembaran mushaf yang dipastikan disalin oleh Ibnu Muqlah ditulis pada bahan kertas katun ${ }^{25}$ (al-qutni) tersimpan di Dār al-Kutub al-Wasā'iq di Kairo. Khat Ibnu Muqlah merupa-

Abdul Malik Bin Marwan $(65-86 \mathrm{H})$ atau pada masa al-Walid bin Marwan (86-96 H).

${ }^{25}$ Seperti diketahui saat itu, penyalinan mushaf lebih banyak dilakukan pada media kertas kulit atau tulang. Sangat sedikit yang ditulis pada media kertas 'Kagid' (kāgid/kertas Baghdad). 
kan titik peralihan dari kufi mushaf ke kufi mutațawwar. Selain itu, pada periode ini berkembang pesat hiasan pada mushaf. Pada masa ini, mushaf Al-Qur'an mulai terlihat indah baik tulisannya yang mulai lentur maupun dibantu dengan hiasan. Selain itu mulai ada peralihan dari kertas kulit ke kertas katun (paper). ${ }^{26}$

Sepeninggal Ibnu Muqlah (w. 328 H/939 M), muncul lagi tokoh khat kaliber dunia, Ibnu al-Bawwāb (w. 413 H). Nama aslinya Ali bin Hilāl al-Kātib. Ia yang mempopulerkan khat gaya lentur sulus dan naskhi. Sejarawan al-Qazwaini mengatakan tentang keajegan karyanya: "Andai Ia diminta untuk menulis satu huruf seratus kali, maka semua tidak akan berbeda."27 Salah satu mushaf Salinan Ibnu al-Bawwāb di antara 64 mushaf karyanya tersimpan di perpustakaan Chester Beatty di Dublin. Mushaf ini ditulis di Baghdad tahun $391 \mathrm{H}(1001 \mathrm{M})$ : ayatnya ditulis dengan gaya naskhi wadih (Bold Naskh). Ibnu al-Bawwāb (w.413 H) merupakan salah satu muara dari perkembangan khat gaya naskhi dari Ibnu Muqlah. Ciri utama khat Ibnu al-Bawwāb yaitu semua ukuran huruf berpedoman pada pada huruf alif, dan tidak terlihat dari tulisannya ukuran huruf yang menyalahi aturan tersebut.

Dua abad setelah wafatnya Ibnu Bawwāb, muncul penyalin mushaf legendaris bernama Yaqūt. Ia bernama lengkap Jamaluddīn Yaqūt bin 'Abdullāh al-Musta'simi (w. 1299 M). Ia dianggap sebagai penutup khattat generasi Baghdad. Yaqūt dijuluki Qiblah al-Khațtâțin karena saat itu para khattat dari dunia Islam bukan hanya dari Arab tapi juga dari Persia dan Turki belajar darinya khat yang enam. Yaqūt dikenal piawai menulis kaligrafi dengan cepat. Satu hari ia menulis 2 juz AlQur'an, 2 mushaf sebulan. Konon ia menyalin 364 mushaf, bahkan ada yang menyebutkan ia telah menyalin 1001 mushaf. Dari Yaqūt, lahir para khattat besar dunia Islam yang bersanad kepadanya yaitu: Syeikh Ahmad bin Sahrawardi al-Bakri (w. 632

\footnotetext{
${ }^{26}$ Kertas sudah banyak digunakan pada penyalinan buku non mushaf.

${ }^{27}$ Zakariyyā bin Muhammad bin Mahmud al-Qazwaini, Āsār Al-Bilād Wa Akhbār Al-'Ibād (Beirut, 1979), 327.
} 
H/1234 M) ${ }^{28}$, Syaikh Argūn bin Abdullah al-Kāmilī al-Bagdādī (w. $744 \mathrm{H} / 1343 \mathrm{M})^{29}$, Syaikh Haidar Jālī, ${ }^{30}$ Nașrullah al-Ṭabīb (w. 740 H/1339 M), dan Mubāraksyah.

\section{Mushaf Mesir: dari Fatimiyyah hingga Mamluk}

Belum ada bukti keberadaan mushaf yang ditulis di negeri Mesir pada abad ke-1 Hijriah. Perkembangan mushaf di Mesir dimulai pada awal atau pertengahan daulah Abbasiyyah. Adapun adanya mushaf di Masjid Husain Kairo yang dinisbatkan pada abad ke-1 Hijriah, tidak lain adalah mushaf yang berasal dari awal Daulah Umayyah. Menurut catatan Sa'ad Māhir, mushaf ini baru ada di Masyhad Husain pada tahun 1887 Masehi, setelah berpindah-pindah dari masjid ke masjid dan dari madrasah ke madrasah yang ada di Mesir. Mushaf tersebut juga memiliki beberapa nama: mushaf Asmā' binti Abu Bakar, mushaf 'Amr, mushaf Usman bin Affan, dan lain-lain. ${ }^{31}$

Dinasti Fatimiyah merentang mulai pertengahan abad ke-4 $\mathrm{H} / 10 \mathrm{M}$ hingga pertengahan abad ke-6 $\mathrm{H}$ selama kurang lebih 270 tahun. Dinasti ini banyak melahirkan ulama, adubba' (sastrawan), dan seniman Mesir. Seorang kaligrafer terkenal bernama Ya'qūb bin Kālis (w. 380 H) menjabat juga sebagai perdana Menteri. Begitu juga perdana Menteri lainnya, Abu Syujā' Muhammad bin al-Asyraf yang menjadi wazir tahun $457 \mathrm{H}$ untuk khalifah al-Mustanșir Abī Tamīm $(427-487$ H) adalah seorang kaligrafer. Menurut al-Muqrizī, di Istana Fitimiyyun terdapat banyak lemari berisi mushaf-mushaf yang ditulis dengan

${ }^{28}$ Menulis 33 mushaf salah satunya mushaf lengkap 30 juz tersimpan di perpustakaan Chester Betty Dublin. Disalin dengan khat sulus pada tahun 701 H/1301 M. berukuran 19 x $27 \mathrm{~cm}$, terdiri dari 493 lembar, tiap halaman terdiri dari 9 baris.

${ }^{29}$ Berasal dari Turki dan hidup di Arab. Selama hidupnya Ia menyalin 29 mushaf dengan khat mushaf Lima buah mushaf lengkap 30 juz masih terawat hingga kini di perpustakaan dan museum di Turki.

${ }^{30}$ Konon Ia pernah menulis mushaf atas perintah Sultan Ilkhan Khazan Mahmud pada awal abad ke-8 H/14 M.

${ }^{31}$ Mushaf ini dinistbatkan kepada Usman. Tapi menurut beberapa pakar, mushaf ini kemungkinan salinan dari Mushaf Usman dan masa penyalinannya antara seperempat akhir abad ke-1 hijriah atau seperempat awal abad ke-2 Hijriah atas perintah Gubernur Mesir Abdul Aziz bin Marwan. 
khat Ibnu Muqlah, Ibnu Bawwāb, dan lainnya. Menurut catatannya, terdapat total 2400 jenis mushaf baik kondisi lengkap, atau perjuz. Mushaf tersebut memiliki khat indah dengan dihiasi emas dan perak. Kemungkinan besar, para penguasa saat itu tidak hanya memerintahkan penyalinan mushaf dengan khat mansub, tetapi juga menghimpun mushaf-mushaf indah yang ada di 'pasaran'. Salah satu mushaf indah yang tercatat adalah sebuah mushaf kiriman Salahuddin al-Ayyubi kepada Sultan Nuruddin Mahmud bin Zanki (541-569 H/1146-1173 M). Menurut catatan al-Muqrizī, mushaf tersebut setiap lembarnya berlapiskan emas, dengan sampul emas dan ditulis dengan tinta emas. Hanya saja al-Muqrizī tidak menyebutkan jenis khat yang dipakai dan asal mushaf tersebut. ${ }^{32}$

Periode berikutnya adalah mushaf daulah Ayyūbiyyah. Beberapa mushaf dari dinasti ini tersimpan di Dar al-Kutub alWas̄à 'iq al-Miṣriyyah di Kairo. Salah satunya mushaf Al-Qur'an dengan khat lentur (layyin) mendekati naskhi disalin pada media kertas warna kekuningan oleh Abdurrahman bin Muhammad bin Abī al-Na'īm tahun 599 H/1202 M masa Sultan Muhammad alKāmil. Mushaf kedua, yaitu mushaf berukuran sedang 27, 5 x 33 $\mathrm{cm}$ yang ditulis oleh Ismā'̄̄l bin Ibrāhīm bin Aḥmad dan berangka tahun $635 \mathrm{H}(1237 \mathrm{M})$ bertepatan periode akhir Sultan Najmuddin Ayyūb berkhat naskhi. Kaligrafer mushaf lain dari dinasti Ayyubiyun antara lain Mas'ūd bin Muhammad bin Mas'ūd al-Ișfahān̄̄ dan Ahmad bin Abdul Az̄̄z (Ibnu al-'Ajami). Nama terakhir adalah seorang kaligrafer yang mendampingi kehidupan Salahuddin al-Ayyubi. Khat yang berkembang saat itu adalah naskhi, (untuk menulis ayat) Kufi, dan sulus (untuk nama surah). Pada masa ini juga berkembang khat yang disebut al$\dot{S u l u s}$ al-Ayyūbi.

Dinasti Mamluk Mesir merupakan kelanjutan setelah Ayyubiyun. Pada masa inilah banyak dihasilkan warisan kebudayaan adiluhung Islam setelah runtuhnya Baghdad tahun 656

${ }^{32}$ Taqiyuddin Ahmad bin Ali al-Muqrizi, Al-Mawā'iz Wa al-I'tibār bi Zikri Al-Mawāqi'i Wa al-Āsār (Kairo: Bulaq, n.d.), 68. 
H/1258 M ke tangan Tartar. ${ }^{33}$ Mamluk dianggap penerus estafet kepemimpinan dalam bidang kaligrafi Islam setelah daulah Abasiyyah jatuh. Para sultan Mamluk memiliki tradisi memberi hadiah mushaf kepada anak, istri maupun orang tua mereka. Termasuk juga wakaf Al-Qur'an untuk madrasah-madrasah dan masjid serta masyhad maupun yayasan ilmiah. Hal tersebut dilakukan dengan cara mengalokasikan anggaran untuk para kaligrafer. $^{34}$

Catatan sejarah merekam seorang ahli kaligrafi mushaf bernama Muhammad bin al-Kasan alias Ibnu al-Afïf (w. 736 H/1335 M) yang berjuluk Syaikh al-Kuttāb (dewa kaligrafer). Konon ia menyalin beberapa mushaf istimewa. Nama lainnya yaitu Muhammad bin Ahmad al-Zaftāwī (w. 806 H/1403 M). Kaligrafer mushaf dari periode akhir Mamluk yaitu Zainuddin Abdurahman bin Yūsuf al-Qāhiri alias Ibnu al-Șā'ig. Ia menyalin mushaf atas perintah Sultan Barbuq (784-801 H/1382-1398 M) berangka tahun $801 \mathrm{H}$. Mushaf kedua atas permintaan Sultan Nasiruddin Faraj (809-815 H/1406-1412 M) berangka tahun 814 $\mathrm{H}$. Keduanya menggunakan khat muhaqqaq. Abad ke-9 $\mathrm{H}$ ada nama Musa bin Ismail al-Hajīn̄̄. Ia menulis mushaf atas perintah Sultan al-Syaikh al-Mu ayyad (815-824 H) dengan khat muhaqqaq.

\section{Dari Mushaf 'Magrib’ ke Andalus.}

Wilayah Magrib atau Barat meliputi Maroko, Tunisia dan Andalus (Spanyol sekarang). Perkembangan khat di Magrib dimulai dari khat mabsut (kaku) hingga khat layyin (lentur) pada pertengahan abad ke-5 H. Belum ditemukan juga mushaf berbahan kertas kulit dengan khat Hijaz. Dari wilayah ini belum ada bukti mushaf yang berasal dari masa Umayyah (abad $1 \mathrm{H}$ ), bahkan mushaf dari sebelum abad ke-3 H/9 M pun tidak ada. Keberadaan mushaf di Magrib mulai banyak ditemukan dari

${ }^{33}$ Peter Jackson, Dari Puncak Barbar, Penaklukan Mongol Ke Dunia Islah Hingga Menjadi Muslim, ed. Fahmi Yamani, 1st ed. (Jakarta: Serambi, 2019), 366.

${ }^{34}$ Șāliḥ, Khaṭ Al-Muṣhaf Al-Sharīf Wa Tațawwaruhu F̄̄ Al-'Ālam AlIslāmī, 286.

${ }^{35}$ Ṣālih, 208. 
abad ke-3 $\mathrm{H}$ tetapi tidak ada keterangan di mana mushaf tersebut disalin dan siapa penyalinnya. Diduga, mushaf-mushaf tersebut sebenarnya berasal dari Iran atau Iraq dengan cara jual-beli. Para amir pada abad ke-3 H biasanya mengutus kafilah ke Baghdad atau Samara untuk mengantarkan upeti/persembahan ke Khalifah Abbasiyyah dan mereka kembali ke Maghrib membawa banyak naskah termasuk mushaf. Dua kota yang menjadi pusat pengembangan naskah Al-Qur'an saat itu yaitu Qairawan dan Tunis. ${ }^{36}$

Terkait mushaf dari Andalus, belum ada bukti mushaf dari Andalus yang berasal dari masa Umayyah awal dan juga masa Abbasiyyah. Inskripsi-inskripsi pada bangunan dan monumen masa Andalus awal menggunakan khat kufi. Adapun monumen dengan khat lentur dan sulus baru ada di abad ke-8 H/ $14 \mathrm{M}$. Mushaf awal di Andalus kebanyakan dari Qairawan dan Tunis. Berdasar catatan sejarah, tradisi penyalinan mushaf dan qiraat di Andalus sangat masif tidak hanya muslim pria tetapi juga para wanitanya. Hanya saja keberadaan mushafnya tidak ada yang tersisa. Hal tersebut, menurut Aziz, disebabkan pembakaran terhadap mushaf saat terjadinya pembantaian umat Muslim Spanyol. Saat itu, kaum muslim dipaksa masuk agama Nasrani. Tidak hanya itu, jika ditemukan mushaf atau lembaran AlQur'an di rumahnya, maka rumahnya digeledah dan pemiliknya dihukum bakar di hadapan masyarakat di alun-alun kota. Hal ini yang menyebabkan tidak ada mushaf tua ataupun lembaran yang berasal dari dan di Andalus.

Menurut para ahli Kaligrafi, di Andalus terdapat dua khat utama yaitu kufi Andalus al-Basīt dan sulus Qordova ataus sulus Andalus. Mushaf tertua dari Andalus tersimpan di Museum Tariq al-Rajab berangka tahun 393 H/ 1002 M. Mushaf ini menggunakan khat kufi mushaf dengan 14 baris tiap halaman. Sebagian besar mushaf Andalus yang masih ada ditulis pada kertas kulit, sebagai bentuk tabarukan kepada para Khalifah Rasyidin dan para pendahulu. Padahal mereka sudah mengenal kertas papirus

${ }^{36}$ Achmad Faizur Rosyad, "Karakteristik Diakritik Mushaf Magribi, Arab Saudi, Dan Indonesia: Studi Perbandingan," SUHUF 8, no. 1 (2015): 69-90. 
dan menggunakannya untuk penulisan selain mushaf. Di ibu kota Andalus, Qordoba, ada dua kaligrafer mushaf pada masa awal yaitu Ibrahim al-Bakri al-Andalusi dan Sulaiman bin Ahmad alias Ibnu Syaikh (w. 440 H/1048 M). Di Malaga ada Ibnu Mufaḍdal yang menyalin 70 mushaf. Sevilla dan Toledo memiliki kaligrafert Abu 'Ammar Muhammad bin Sulaymān (523 H/1133 M). Kota Valencia terdapat nama Khalafa bin Sulaiman yang terkenal dengan mushafnya yang menggunakan tinta berbeda warna. Nama-nama mereka tidak didapatkan dari tinggalan mushaf mereka, tetapi didapatkan dari buku-buku tentang khat. Tidak ada tinggalan generasi Andalus yang tersisa hingga kini. $^{37}$

\section{Mushaf Wilayah Turki Usmani}

Turki di buku ini merujuk pada era Turki Usmani yang berdiri abad ke-15 M. Kaligrafer Turki Usmani memiliki kontribusi signifikan pada perkembangan khat Arab mulai abad ke-9 H/15 M utamanya pada mulai zaman Sultan Salim I (918-926 H/1512-1520 M). Pada masanya, Ia mengumpulkan para ahli khat baik dari Syam, Iraq, Iran maupun Mamluk Mesir untuk meramaikan khazanah khat mushaf di Turki Usmani. Turki Usmani juga mengangkut kurang lebih 54 mushaf indah dan istimewa dari kota Tabriz di antaranya Salinan Syah Mahmud alNisaburi (khat nasta'liq). Sultan memboyong khattat dari Ardibil bernama al-Zāhir al-Irdibili (w. 932 H) dan Qāsim al-Tabrizī ke Istambul hingga mukim dan wafat di sana.

Kaligrafer asli Turki yang berpengaruh besar yaitu Hamdallāh al-Amasī ibnu al-Mustafa Didah. Ia belajar khat pada Syaikh Khairuddin Marasī murid Abdullāh al-Ṣ̄rafī murid Yaqūt al-Musta'șimi. Ia menguasai enam gaya khat dan menyalin setidaknya 47 mushaf dengan ribuan bagian Al-Qur'an (alRub'āt). Salah satu mushafnya tersimpan di Museum Topkapi berangka tahun $901 \mathrm{H}$. Pernah juga menulis mushaf untuk Sultan

${ }^{37}$ Tampaknya uraian penulis tentang mushaf di Andalus belum diperkuat data lain. Lihat, Nuria Martínez-de-Castilla- Muñoz, 'Qur'anic Manuscripts from Late Muslim Spain: The Collection of Almonacid de La Sierra," Journal of Qur'anic Studies 16, no. 2 (2014): 89-90. 
Bayazid II. Tinta yang digunakan biasanya merah, biru dan hijau. Hiasan yang khas yaitu awan Cina. Hiasan ini dikerjakan oleh orang khusus yang bekerja pada Istana sultan. Ciri khas lainnya: nama surah ditulis dengan tinta putih dengan bergaris pinggir; dengan latar warna emas; dan menggunakan khat naskhi. ${ }^{38}$

Periode khat Turki Usmani berikutnya adalah era Maula Ahmad Qurrah Ḥuṣārī (w. 963 H/1555 M). Ia memiliki peran penting dalam pengembangan gaya naskhi dan sulus. Lewat tradisinya seolah menjadi pakem bahwa menulis Al-Qur'an: ayatnya menggunakan gaya naskhi dan nama surah menggunakan gaya sulus. Ia memiliki mushaf yang dikenal dengan mushaf Qurrah Hușāā̄ tersimpan di Museum Topkapi. Mushaf berukuran 41 x $62 \mathrm{~cm}$ ini tidak sampai selesai ditulisnya, kemudian dilanjutkan oleh anaknya Hasan Qurrah Hușārī alias Hasan Jabalī. Mushaf ini menggunakan anggaran negara sangat besar: material emas untuk teks matan dan iluminasi, bahan kertas, tinta, dan lainnya. Untuk produk spesial ini sultan juga memesankan kotak khusus mushaf ini dari para pengrajin khusus. Kotak berukir hiasan sulur daun, geometri, dan kutipan ayat.

Kaligrafer mushaf yang masyhur pada abad ke-11 H/17 M yaitu Hāfiz 'Us̉mān (w. 1110 H/1698 M). Ia salah seorang khattat jenius masa Usmani bahkan dunia Islam. Ia dikenal dengan Syaikh al-Ṡālis alias Hāfiz Al-Qur'ān. Mengajar khat masa Sultan Mustafa ke-II (1106-1115). ${ }^{39}$ Ia menguasai khat naskhi, muhaqqaq, sulus, raihan, dan diwani. Mushafnya yang berkhat naskhi dicetak di Istambul. Pertama kali dicetak batu tahun 1686 dan mendapat sambutan hangat dari belahan dunia Islam. Cetak ulang tahun 1879 dua abad sepeninggalnya. Nama lain yang menggeluti khat naskhi untuk mushaf yaitu, Qāyisy Zādah. Pada akhir abad ke-19 M ada nama Haji Ahmad Kāmil, penyalin mushaf di Istambul yang karyanya dicetak lebih dari

${ }^{38}$ Șāliḥ, Khaṭ Al-Muṣhaf Al-Sharīf Wa Tațawwaruhu Fī Al-'Ālam AlIslāmī, 457-60.

${ }^{39}$ Beberapa Sultan Turki Usmani adalah kaligrafer: Sultan Murad ke-II (824-855 H/1421-1451 M); Bayazid II (918-886 H/1481-1512 M); Sultan Murad III (982-1003 H/ 1574-1595 M); Sultan Suliaman II (1099-1102 H/1687-1691 M). Nama terakhir pawai dalam khat sulus, sedangkan lainnya menguasai khat sulus dan naskhi. 
sekali. Kāmil mendapatkan penghargaan dari pemerintah Utsmani tahun 1914 dan dijuluki Ketua Para Khattat. ${ }^{40}$

Kaligrafer Turki Usmani menjadikan naskhi sebagai khat standar dalam penulisan ayat Al-Qur'an. Khat ini dijuluki sebagai khādim al-Qur'ān (pelayan Al-Qur'an). Berkembang juga khat diwani, ta'liq dan riq'ah. Khat nonnaskhi banyak digunakan oleh para kaligrafer Turki tetapi tidak untuk mushaf. Khatkhat tersebut tidak cocok untuk menulis Al-Qur'an yang tujuannya untuk dibaca, terutama khat diwani. Meskipun begitu, ada juga mushaf yang disalin dengan gaya diwani.

\section{Mushaf-mushaf Pinggiran: India, Cina dan Indonesia}

Islam telah masuk ke India masa khalifah Muawiyah bin Abi Sufyan (41-60 H/661-680 M) yang dimulai oleh Mulahhab bin Abi Șafrah. Kemudian dilanjutkan pada masa Abbasiyyah dan terakhir masa Ghazwani. Kehadiran Islam ke India bukan semata para prajurit perang, tetapi juga pedagang, dan tokoh agama. Kedatangan mereka, boleh jadi membawa mushaf maupun bagian dari mushaf. Beberapa mushaf tua berasal dari anak Benua India (Jainapur, Gujarat, dan Kashmir) tersimpan di Museum Metropolitan New York berasal dari abad ke $18 \mathrm{M}$. ditulis dengan khat naskhi dan tanda surah dengan khat sulus.

Di masa dinasti Moghul, banyak keluarga kerajaan yang cinta naskah dan seni pernaskahan. Saat pindah dari Asia Tengah ke India, Ia membawa isi perpustakaannya yang berisi ribuan naskah. Jumlahnya berlipat ganda saat cucunya, Jalāluddin Akbar Syah menjadi amir (963-1014 H/1556-1605 M). Saat itu perpustakaannya memiliki 24 ribu naskah dari berbagai bahasa: Persi, Arab, Turki, Yunani, Kashmir. Mertua sultan Akbar adalah seorang ulama bernama sultan Aranung Zeb. Ia hafal AlQur'an dan menulis mushaf dengan gaya mansub. Salah satu mushafnya dikirim ke Madinah.

${ }^{40}$ Selain naskhi, ia juga menguasai khat kufi, dan diwani. Kemampuannya banyak digunakan Amir Mesir, Ibrahim bin Muhammad Ali alKabīr, menulis inskripsi pada monumen di beberapa universitas di Kairo. Terkahir ia menjadi professor kaligrafi pada akademi seni di Istambul hingga wafat tahun 1941. 
Khat naskhi banyak berkembang untuk penulisan mushaf pada dinasti Delhi. Khat ini merajai penulisan mushaf di India sejak abad $16 \mathrm{M}$ dan setelahnya. Seperti yang terjadi pada dinasti Safawi di Iran. Pada masa Sultan Akbar, ciri khas mushaf India menggunakan banyak varian khat masyhur. Salah satu contohnya mushaf satu jilid yang disalin untuk Raja Akbar Hamdallah alHusaini di kota Lahore (981 H/1573-74). Mushaf terdiri dari 17 baris: 3 baris khat muhaqqaq besar, di antara tiga baris tersebut terdapat tujuh baris khat naskhi ukuran kecil. Khattat lainnya yaitu Abdul Baqi, menyalin mushaf 30 juz dalam 30 lembar kertas. Mushafnya tersimpan di museum Teheran.

Salah satu jenis khat yang berkembang di anak benua India adalah khat Bihari. Khat ini cabang dari khat naskhi. Berdasarkan tinggalan yang ada, khat ini sudah ada akhir abad ke-10 H/16 M), dan awalnya berasal dari Asia Tengah. Nama Bihar berasal dari nama daerah di Bengali. Salah satu mushaf dengan khat ini ditulis dalam 30 juz oleh Mạ̣mūd bin Sya'bān pada tahun $801 \mathrm{H} / 1399$ M. Ia sekaligus sejarawan pada masa Sultan Nusrah Syah (797-802 H/1394-1399 M). mushafnya bermatan ayat dengan khat Bihar, dan nama surah dengan khat Kufi berekor. Karakteristik khat Bihar, pertama, tidak ada kaidah khusus penulisan huruf, contohnya alif, posisinya kadang rendah-kadang tinggi. Kedua, bentuk hurufnya kadang berbedabeda seperti penulisan huruf kaf. Ketiga, beberapa huruf yang 'berperut' ditulis tidak seimbang, kadang panjang kadang pendek seperti pada huruf $y a$ '.

Adapun di Indonesia seperti Banten, Madura, Lombok, Kalimantan dan Sulawesi terdapat mushaf yang menggunakan khat naskhi. Kertas yang digunakan adalah kertas khas yang tidak ada di Timur Tengah, dari kulit kayu yang dinamakan kerta daluwang. Mushaf Indonesia juga sudah lengkap dengan harakat dan tanda baca; halaman mushaf tidak ada hiasan; tanda ayat berupa lingkaran kecil tanpa hiasan; penulisan kata ayat dan makiyyah dibuat seperti pilinan huruf, penulisan huruf $\sin$ pada basmalah juga tidak pengikuti kaidah sempurna karena giginya 
lebih tinggi. Hiasan awal mushaf terinspirasi hiasan yang ada di anak benua India abad ke-16 s.d. $18 \mathrm{M}^{41}$

\section{Ilmu Khat sebagai Alternatif Metode Indentifikasi Mushaf}

Meski memakai judul khat mushaf, tetapi pembahasan dalam buku ini tidak hanya tentang khat. Setiap mushaf diuraikan deskripsi kodikologinya, tanda baca, jenis kertas, jenis khat, tinta, dan asal muasal kenapa manuskrip tersebut bisa sampai di lokasi tersebut. Disertakan juga hasil analisis uji karbon (radiocarbon dating) untuk beberapa naskah. Hasil penanggalan-nya dibandingkan dengan sejarah mushaf yang sudah masyhur di kalangan sejarawan mushaf Al-Qur'an. Menariknya, objek kajiannya mushaf Al-Qur'an dari generasi Islam masa lalu hingga masa kini, dan meliputi semua 'wilayah' Islam. Melalui rujukan yang ia gunakan, pembaca mendapatkan gambaran keagungan kebudayaan mushaf Islam masa lalu. Pembaca diajak menikmati mushaf-mushaf periode Khilafah Rasyidin mulai dari khatnya yang terasa asing bagi muslim kiwari dan ayat yang tanpa tanda titik dan tanda syakl. Pembaca juga diajak menikmati mushafmushaf menawan dari masa kejayaan Baghdad, menyebrang ke Mesir dari masa Fatimiyyah, Ayyubiyyah, Mamluk, Persia, Asia Tengah, Turki Usmani, India, hingga Asia Tenggara (Indonesia) dan Cina.

Melalui buku ini, pembaca dapat menikmati pembabakan khat mushaf di dunia Islam. Khat apa yang berkembang pada masa awal, pertengahan hingga kontemporer Islam dijabarkan dalam buku ini. Selain itu, nama-nama para khat serta jaringan para penulis mushaf utamanya dari zaman Abbasiyyah di Baghdad juga dipaparkan. Buku ini juga menghimpun data di mana mushaf-mushaf dari setiap daulah Islam itu kini disimpan. Dari data yang diuraikan Aziz, tampaknya ia memulai kajian buku ini dari nama-nama para kaligrafer dunia. Nama itu dipakai untuk melacak keberadaan mushaf karya-karya mereka. Dari mushaf tersebut, kemudian diuraikan unsur-unsur mushaf mulai dari jenis khat, warna tinta, bahan kertas, tanda titik, syakl,

${ }^{41}$ Șāliḥ, Khaṭ Al-Muṣhaf Al-Sharīf Wa Tațawwaruhu F̄̄ Al-'Ālam AlIslāmī, 502-4. 
kolofon, ragam hias, pencipta ragam hias dan lain-lainnya. Ia juga menguraikan asal muasal mushaf, harga, keistimewaannya dan kenapa bisa pindah dari satu kota ke kota lain. Untuk mendapatkan jaringan sanad dan melacak siapa guru dari siapa serta siapa muridnya, ia menggunakan buku-buku taräjim (biografi) yang sangat melimpah datanya. Buku dari khazanah lama memberikannya data jumlah mushaf yang ditulis oleh seseorang dan mushaf di beberapa istana sultan. Meskipun boleh jadi mushafnya sudah tidak sampai ke zaman sekarang. Untuk menulis buku ini, penulisnya menjenjelajah berbagai perpustakaan dan museum besar dunia: mulai dari Amerika, Eropa, India dan Asia. Tentang pembabakan kaligrafi bisa dibantu lewat karya al-Faruqi, The Cultural Atlas of Islam. ${ }^{42}$

Ada ungkapan bahwa Al-Qur'an itu ilahiah, sedangkan mushaf itu ilmiah. Sebuah mushaf Al-Qur'an bisa melintas zaman dari masa Nabi hingga kini masih terus dilengkapi dengan ilmu bantu. Beberapa di antaranya ilmu tanda baca (dabt), ilmu syakl, ilmu rasm, ilmu waqfu wal ibtida', ilmu addil ayy, ilmu makki madani, ilmu qira'at, dan lain-lainnya ${ }^{43}$. Masing-masing ilmu itu sudah memiliki sistem baku yang satu sama lain saling mengait dan menguatkan. Contoh, kapan ilmu tanda baca (dabt $)$ mulai dikenal; menggunakan tinta apa, bentuknya bagaimana dan bagaimana perkembangannya dalam tiap zaman. Ilmu dukung demikian yang mengawal perkambangan mushaf dari zaman ke zaman. Dengannya bisa diintetifikasi sebuah mushaf berasal dari daerah mana dan dari rentang abad keberapa. Selain dari disiplin ilmu-ilmu Al-Qur'an, ada juga Paleografi, Sejarah Seni, Ortograpi, Filologi dan metode uji karbon.

Selain ilmu bantu yang tersebut di atas dan biasa diajarkan dalam bidang ulüm al-qur'ān, ada satu ilmu lain yang dapat digunakan yaitu ilmu khat/Kaligrafi. Metode ini yang digunakan

${ }^{42}$ Isma'il R. al-Faruqi, Atlas Budaya Islam: Menjelajah Khazanah Peradaban Gemilang, ed. Ilyas Hasan, III (Bandung: Mizan, 2001), 391 dan 399.

${ }^{43}$ Hakim, "Metode Kajian Rasm, Qiraat, Wakaf Dan Dabt Pada Mushaf Kuno (Sebuah Pengantar)."

${ }^{44}$ Yasin Dutton, "Qur'ans of the Umayyads: A First Overview," Journal of Qur'anic Studies 18, no. 1 (2016): 153. 
Aziz dalam buku ini untuk menganalisis mushaf-mushaf dari seluruh dunia. Dalam sejarah perkembangan khat ada namanama kaligrafer dari setiap zaman seperti Ibnu Muqlah, Ibnu Bawwāb, Yaqūt, Mubaraksyah, dan lain-lain. Setiap daerah ada jenis-jenis khat seperti khat hijaz, kufi, kufi Mabsut, kufi layyin, mansub, raihan, sulus, muhaqqaq, naskhi, nasta'liq, qairawan, bihari, naskhi ayyubi, naskhi Cina dan lain-lain. Selain mewakili wilayah tertentu, jenis khat di atas juga mewakili zamannya. Contohnya khat hijazi dan kufi mabsut, keduanya tidak lagi berkembang dan tidak digunakan pada masa akhir Abbasiyyah. Khat mansub, naskhi dan raihan baru mulai abad ke-3 Hijriah. Contohnya, jika ada mushaf diklaim dari abad ke-1 H (masa Khalifah Rasyidin dan Umayyah) tetapi menggunakan khat mansub atau khat kufi lain, maka klaim itu terbantahkan dengan sendirinya. Karena khat mansub baru muncul masa Ibnu Muqlah abad ke-4 $\mathrm{H}^{45}$

Identifikasi angka tahun paling ideal yaitu dengan menggunakan kolofon naskah. Hanya saja tidak semua naskah mushaf berkolofon. Hal tersebut terjadi karena banyak sebab di antaranya terkait aspek teologis: keyakinan tentang keikhlasan dalam penyalinan Al-Qur'an. Dalam proses identifikasi angka tahun mushaf kuno, penggunaan analisis ilmu khat tidak bisa berdiri sendiri karena rentang waktu yang dihasilkan masih dalam rentang abad. Harus dilengkapi dengan ilmu lainnya yang bisa mendekatkan angka tahunnya seperti ilmu ragam hias, analisis kertas, dan lainnya. Selain itu, metode ini (khat) juga belum bisa mengidentifikasi asal mushaf secara mutlak, terutama mushaf dengan khat 'pasaran' seperti naskhi, raihan, dan muhaqqaq. Meskipun demikian, metode ini menjadi alternatif dari metode yang sudah ada dan selama ini didominasi ilmu-ilmu kequr'anan.

\section{Mushaf Indonesia bagian dari Mushaf Dunia}

Melihat daftar isi buku ini yang mencantumkan Indonesia (Asia Tenggara) sebagai salah satu wilayah yang mushafnya ikut dikaji, cukup menggembirakan. Karena jarang sekali kajian

${ }^{45}$ al-Faruqi, Atlas Budaya Islam: Menjelajah Khazanah Peradaban Gemilang, 399. 
peradaban Islam mengikutsertakan kebudayaan Islam Indonesia dalam kajian mereka. Biasanya, kajian kebudayaan Islam dimulai dari masa kejayaan Islam, tentang kejayaan Islam dan berakhir pada era itu pula. Wilayah-wilayah Islam yang jauh dari 'pusat' lahirnya kebudayaan Islam dan tidak memiliki sejarah kekuasaan global jarang dilirik. Untuk hal ini, buku ini menjadi istimewa dan patut diapresiasi. Hanya saja, ketika masuk bagian tentang kajian mushaf di Indonesia, datanya sangat minim dan tidak valid. Bagaimana tidak, ada foto Masjid Baitrurahman Aceh, tetapi pada bagian keterangan tertulis bahwa ini masjid terbesar yang ada di Indonesia letaknya di Jakarta. Foto lainnya tentang museum Al-Qur' an kayu yang ada di Palembang, ditulisnya museum di Jakarta.

Terkait kajian di Indonesia, mushaf yang dikaji hanya satu mushaf berasal dari Jawa. Padahal, berdasarkan penelitian Ali Akbar, ada sekitar seribu lebih (1075) mushaf tulis tangan Indonesia atau yang berasal dari Indonesia. Mushaf-mushaf ini ditulis mulai dari abad ke-17 hingga akhir abad ke-19 M. ${ }^{46}$ Sebagian besar mushaf Indonesia berasal dari abad ke-19 M. Meskipun begitu, jejak keberadaannya sudah ada sejak abad ke$13 \mathrm{M}$ seperti terekam dalam risalah perjalanan Ibnu Bațuṭah ke Aceh. Tempat penyalinanya pun tidak hanya di Jawa, tapi hampir merata di wilayah-wilayah lama seperti Aceh, Kepulauan Riau, Palembang, Banten, Cirebon, Surakarta, Yogyakarta, Gresik, Madura, Lombok, Makassar, Ternate, Pontianak, dan lain-lain. ${ }^{47}$ Selain itu, mushaf Indonesia juga tidak sedikit yang memiliki ragam hias indah seperti mushaf-mushaf dari belahan dunia Islam lain. Akbar mengatakan bahwa seni mushaf nusantara memiliki ciri khas tersendiri dibanding dengan induk-

${ }^{46}$ Rinciannya: 663 Koleksi dalam negeri; 412 koleksi luar negeri. Selain itu, terdapat juga cetakan litografi sejumlah 26 mushaf: 24 mushaf cetakan Singapura dan 2 mushaf cetakan Palembang. Lihat, Ali Akbar, "Naskah Qur'an Nusantara: Kajian Kaligrafi" (Universitas Indonesia, 2016), 52.

${ }^{47}$ Abdul Hakim, "Khazanah Al-Qur'an Kuno Bangkalan Madura: Telaah Atas Kolofon Naskah," SUHUF 8, no. 1 (2015): 24; Ali Akbar, "Mushaf Sultan Ternate Tertua Di Nusantara?: Menelaah Ulang Kolofon," Lektrur 8, no. 2 (2010): 284. 
nya yang ada di Timur Tengah. Sebagaimana terlihat dari tinggalan mushaf-mushaf kuno yang dihasilkan dari keraton. ${ }^{48}$ Tampaknya, standar metode yang digunakan Aziz untuk mengkaji mushaf dalam buku ini, dikecualikan untuk mushaf Indonesia dan Cina.

Kalau dilihat dari sumber rujukan yang hanya menggunakan satu buku untuk kajian mushaf Indonesia, diduga kuat Aziz tidak datang ke Indonesia langsung. Ia menggunakan buku tentang 'Sejarah Kebudayaan Asia Dekat' cetakan tahun 1977. Tidak ada rujukan langsung terkait perkembangan mushaf. Lewat rujukan tersebut, ia lebih banyak memaparkan proses masuknya Islam ke Indonesia ketimbang ulasan mushaf Indonesia. Buku ini mengklaim bahwa para dai yang ada di Indonesia berasal dari Anak benua India terutama abad ke-16 dan 17 Masehi. Padahal banyak sumber menyatakan Islam masuk ke Indonesia tidak dari dan ke satu tempat sebagaimana teori (Gujarat, Arab, Iran dan Cina) serta dengan berbagai macam cara (dakwah, niaga, seni, perkawinan, dan lainnya). ${ }^{49}$ Secara garis besar teori masuknya Islam ke Indonesia dapat dibagi ke dalam dua kategori. Ada yang mengatakan Islam datang ke Indonesia abad pertama Hijriah (abad ke-7 M). Teori pertama ini dianut oleh W.P. Groeneveldt, T.W. Arnold, Syed Naguib Al-Attas, George Fadlo Hourani, J.C. van Leur, Hamka, Uka Tjandrasasmita dan lainnya. Kelompok kedua mengatakan kedatangan Islam ke Indonesia dimulai abad ke-13 M. Teori kedua ini diutarakan oleh C Snouck Hurgronje, J.P. Moquette, R.A. Kern, Haji Agus Salim dan lainnya. ${ }^{50}$

Terkait kajian mushaf Indonesia dalam buku Aziz, porsi kajian mushaf hanya sepintas, lebih banyak uraian tentang

${ }^{48}$ Akbar, "Naskah Qur'an Nusantara: Kajian Kaligrafi."

${ }^{49}$ Azyumardi Azra, Jaringan Ulama Timur Tengah Dan Kepulauan Nusantara Abad XVII \& XVIII: Akar Pembaruan Islam Indonesia (Jakarta: Kencana, 2013), 2-13; Hendra Kurniawan, "The Role of Chinese in Coming of Islam to Indonesia: Teaching Materials Development Based on Multiculturalism," Paramita - Historical Studies Journal 27, no. 2 (2017): 238-48.

${ }^{50}$ Uka Tjandrasasmita, Arkeologi Islam Nusantara (Jakarta: Kepustakaan Populer Gramedia, 2009), 11-13. 
masuknya Islam ke Indonesia. Hal ini sangat disayangkan karena Indonesia adalah negara dengan komposisi umat Islam terbesar sejagat. Menghadirkan kebudayaan Islam Indonesia, yang jumlah penduduknya terbesar kelima dunia, berarti menghadirkan Islam ke tingkat dunia. Kendati demikian usaha Aziz yang berasal dari Iraq merangkul Islam 'jauh' perlu diapresiasi. Usaha ini juga membuka peluang bagi peneliti lain untuk melengkapinya data yang belum tersedia atau belum valid pada masa mendatang. Kekurangan ini hanya noktah kecil yang tidak mengurangi bobot buku ini.

Terkait mushaf Cina, seperti kasus mushaf Indonesia, Aziz belum menemukan mushaf yang lebih tua daripada abad ke-16 M. Kalaupun ada, berasal dari wilayah Islam lainnya seperti Iraq, Iran, Asia Tengah. Mushaf tertua yang dipastikan ditulis di Cina berasal dari abad ke-16 M menggunakan khat muhaqqaq. Tiap halaman terdiri dari 5 baris, pembatas ayat menggunakan gambar tangkai daun. Mushaf lainnya yang tersimpan di British Library dari abad ke-16 M, 13 baris, sudah ada tanda titik dan harakat, khat muhaqqaq. Di Cina, khat jenis ini mengalami akulturasi dengan kaligrafi lokal Cina. Sayang sekali, tradisi mushaf di Cina tidak dibarengi dengan bukti nama-nama penyalin mushaf. Paparan pada subjudul tentang mushaf Cina, panjang lebar tentang masuknya Islam ke Negeri Cina. Seolah-olah Cina dimasuki Islam saja sudah bagus dan tidak perlu lagi kajian mushafnya. Bahasannya lebih banyak tentang masjid-masjid lama di Cina seperti pada subbab Indonesia. Pada bagian ini (Cina) juga hanya mengambil satu rujukan dan hanya beberapa mushaf.

\section{Mutualisme Kaligrafi dan Al-Qur'an}

Kaligrafi Arab mengalami dinamika yang pesat melebihi mazhab-mazhab tulisan lain di dunia berkat Islam ${ }^{51}$. Faktor fundamental perubahan ini, menurut Blair (2006), ini tidak lepas

${ }^{51}$ al-Faruqi, Atlas Budaya Islam: Menjelajah Khazanah Peradaban Gemilang, 390; Didin Sirojuddin A.R., "Peta Perkembangan Kaligrafi Islam Di Indonesia," Al-Turā̇s 20, no. 1 (2014): 220. 
dari 'berkah' Al-Qur'an. ${ }^{52}$ Wahyu pertama Al-Qur'an berbicara tentang perintah membaca dan menulis (Qs. al-'Alaq/96: 1-5) ${ }^{53}$. Wahyu pertama tersebut didukung oleh ayat-ayat lain yang menjadi katalisator pertumbuhan kaligrafi seperti Qs. al-Qalam/ 68: $1{ }^{54}$ Qs. al-Qāf/50: 17-18; ${ }^{.5}$ Qs. al-Hāqqa/69: $18-19 .{ }^{56}$ Pertumbuhan pesat kaligrafi karena faktor Al-Qur'an dapat dilihat dan dibandingkan dengan era sebelum kenabian. Selama 1.500 tahun sejak periode Hiroglip hingga kedatangan Islam, hanya ada dua gaya khat yakni Musnad dan Nabati. ${ }^{57}$ Pada abad ke-VII Masehi masyarakat Arab sudah mengenal tulisan (seni tulis) dengan bentuk sederhana. Namun, kepandaian itu tidak banyak dipraktikkan dan dikembangkan oleh masyarakat Arab saat itu. Mereka lebih terampil dalam menghafal dibandingkan menulis. Menurut alFaruqi, Al-Qur'an-lah yang kemudian membakar dan memberikan sentuhan keagamaan orang Arab gurun dan orang Semit tetangganya di Mesopotamia untuk mengembangkan Kaligrafi. Al-Qur'an berpengaruh menjadikan kaligrafi bentuk seni paling penting dalam budaya Islam. Pengaruh dan keutama-annya ditemukan pada setiap wilayah dunia Muslim, pada setiap abad

${ }^{52}$ Sheila S. Blair, Islamic Calligraphy (Edinburgh: Edinburgh University Press, 2006), 3-4.

${ }^{53}$ Artinya: "Bacalah dengan menyebut nama Tuhanmu yang menciptakan!. Dia menciptakan manusia dari segumpal darah. Bacalah! Tuhanmulah yang Mahamulia, yang mengajar manusia dengan pena. Dia mengajarkan manusiia apa yang tidak diketahuinya."

${ }^{54}$ Artinya: "Nūn. Demi pena dan apa yang mereka tuliskan."

${ }^{55}$ Artinya: "(ingatlah) ketika dua malaikat mencatat (perbuatannya). Yang satu duduk disebelah kanan dan yang lain di sebelah kiri. Tidak ada suatu kata pun yang terucap, melainkan ada di sisinya malaikat pengawas yang selalu siap mencatat"

${ }^{56}$ Artinya:" Adapun orang yang diberi catatan amalnya di tangan kanannya, dia berkata (kepada orang di sekelilingnya) ambillah (dan) bacalah kitabkku (ini)"

${ }^{57}$ Alain George, "The Qur'an, Calligraphy, and the Early Civilization of Islam," in A Companion to Islamic Art and Architecture, ed. Finbarr Barry Flood, 1st ed. (New Jersey: John Wiley \& Sons, 2017), 110-111; Sirojuddin A.R., "Peta Perkembangan Kaligrafi Islam Di Indonesia," 220. 
dalam sejarah Islam, pada setiap cabang produksi dan pada setiap tipe objek seni yang dapat dibayangkan. ${ }^{5}$

Perkembangan kaligrafi tumbuh sebanding dengan minat baru dalam teks Al-Qur'an sebagai pembimbing untuk semua pemikiran dan aktivitas, keinginan untuk menjaganya dan menyampaikannya secara akurat. ${ }^{59}$ Menurut Habibullāh, sebagai-mana dikutip Sirojuddin, secara garis besar perkembangan kaligrafi mushaf terbagi dalam enam periode. Periode pertama, pertumbuhan awal yaitu saat khat kufi belum bertanda baca, saat itu Islam baru mulai melebarkan sayap ke luar wilayah semenanjung Arab. Problem ini teruraikan dengan adanya inovasi tanda baca gagasan Abu al-Aswad al-Du'ali (w. $69 \mathrm{H}$ ). Perlu diingat bahwa tanda baca tersebut awalnya diperuntukkan sebagai alat bantu baca Al-Qur'an. Periode kedua, bermula dari masa akhir kekuasaan Daulah Umayyah dan awal Daulah Abbasiyyah (alMakmun). Ibnu Nadīm mencatat terdapat 24 hingga 36 gaya khat. Periode ketiga, yaitu penyempurnaan anatomi huruf dengan tokohnya Ibnu Muqlah (w. 328 H). Ia mengkodifikasi gaya kaligrafi yang bermacam tersebut menjadi 12 kaidah rujukan bagi semua gaya.

Periode keempat, pengembangan khat karya Ibnu Muqlah (w. $328 \mathrm{H}$ ) yang dipelopori oleh Ibnu al-Bawwāb (w. $413 \mathrm{H}$ ). Pada periode ini juga berkembang pesat hiasan mushaf, karena Ibnu al-Bawwāb sendiri menambahkan unsur zukhruf (hiasan) pada khat yang jadi obyek ekperimennya. Periode kelima, adalah masa pengolahan gaya dan penetapan al-Aqlām al-Sittah (khat enam yaitu sulus, naskhi, raihan, muhaqqaq, tauqi' dan riqa'). Tokoh pada periode ini yaitu Yaqūt al-Musta'simi (w. 698 H). Ia mengembalikan hukum-hukum dua pendahulunya, Ibnu Muqlah dan Ibnu al-Bawwāb, pada asas geometri dan titik yang populer di zamannya, sekaligus memperhalus gaya-gaya yang sedang berkembang saat itu. Dengan sosok Yaqūt yang dikenal juga dengan julukan kaligrafer seribu mushaf, periode ini menghasilkan penemuan-penemuan baru ratusan gaya khat. Periode

\footnotetext{
${ }^{58}$ al-Faruqi, Atlas Budaya Islam: Menjelajah Khazanah Peradaban Gemilang, 390.

${ }^{59}$ al-Faruqi, 392.
} 
keenam, ditandai munculnya tiga gaya khat (ta'liq, nasta'liq, dan syikasteh) dari para kaligrafer Iran. ${ }^{60}$ Pemetaan Habibullah terkesan hanya mengakomodir perkembangan kaligrafi mushaf wilayah Timur Tengah. Berbeda dengannya, Al-Faruqi memetakan perkembangan khat mushaf bukan hanya berdasarkan masa, tetapi juga berdasar wilayah dan bentuk tulisan. Cakupan juga meliputi wilayah nonArab seperti Turki, Asia Tengah, India, dan Timur Jauh. ${ }^{61}$

\section{Small is Beautiful: dari Rasm hingga Tanda Baca Mushaf}

Pada Subbab terakhir ini akan dibahas detail kecil yang luput dari buku ini: Ukuran, ragam hias, nomor koleksi dan lainnya. Deskripsi mushaf pada buku ini, untuk beberapa mushaf, kadang ada ukuran, kadang tidak ada. Ukuran objek menjadi penting untuk pembaca yang tidak berinteraksi langsung dengan objek kajian. Apalagi ukuran mushaf dari masa lampau, tentu berbeda dengan mushaf masa kini. ${ }^{62}$ Contohnya, sebuah mushaf berkhat kufi mabsut pada kertas ukuran $50 \times 70 \mathrm{~cm}$ dan berisi 3 baris tiap halaman. Gambaran seperti itu membantu pembaca mendapatkan gambaran seberapa besar ukuran khat dan seberapa besar qalam (pena) yang digunakan kala itu. Masalah seperti ini kerap muncul pada penelitian mushaf. Selain ukuran ada juga aspek foto. Pada pembahasan mushaf Mesir, foto yang disuguhkan berkualitas lebih rendah dari foto mushaf dari daerah lain. Hal tersebut kemungkinan disebabkan terbatasnya akses Aziz ke mushaf-mushaf dari Mesir.

221.

${ }^{60}$ Sirojuddin A.R., "Peta Perkembangan Kaligrafi Islam di Indonesia,"

${ }^{61}$ al-Faruqi, Atlas Budaya Islam: Menjelajah Khazanah Peradaban Gemilang, 399.

${ }^{62}$ Ludgardis Lipa, Nurdin Hidayah, and Dendy Sundayana, "Pengembangan Fasilitas Interpretasi Berbasis QR Code Menggunakan System Development Life Cycle (SDLC): Studi Kasus di Museum Negeri Sri Baduga Bandung" Barista: Jurnal Kajian Bahasa Dan Pariwisata 6, no. 2 (2019), 181.; Ridha Anggi Nurkholisha and Lydia Christiani, "Evaluasi Kebijakan Pengembangan Koleksi Di Perpustakaan Nasional Republik Indonesia (Pnri) Pada Naskah Nusantara," Jurnal Ilmu Perpustakaan 7, no. 3 (2018), 81-90. 
Deskripsi ragam hias pada buku ini juga kurang detail. Contoh, pada bahasan mushaf Cina, Aziz menjelaskan bahwa hiasan mushaf Cina sama dan diduga kuat berasal dari Iraq, tetapi tidak ia dijelaskan ragam hias di Iraq seperti apa. Itu juga terjadi pada uraian beberapa mushaf lain. Hal tersebut dapat dimaklumi karena uraian tentang ragam hias hanya melengkapi dan memperkuat analisis khat. Lebih menarik lagi, buku ini tidak sedikitpun menyinggung penggunaan rasm pada mushaf lama. Padahal, hampir semua aspek ilmu bantu ulūm al-qur'ān dibahasnya seperti ilmu tanda baca (dabt) dan tanda harakat (syakl). Kalau saja terdapat sekilas info rasm pada tiap deskripsi naskah, maka bisa menjadi informasi awal melakukan kajian aspek ini. Mushaf salinan Ibnu al-Bawwāb, contohnya, ternyata menggunakan rasm yang zaman sekarang disebut rasm qiyasi (imlà' $i$ ). Tidak adanya info aspek rasm bisa dikarenakan dua hal: pertama, minimnya data kajian rasm mushaf tua yang bisa langsung dimanfaatkan dalam tulisan. Kedua, belum bertemunya rasm sebagai teori yang dikaji di ruang belajar dan rasm sebagai aplikasi pada mushaf kuno. ${ }^{63}$

Buku ini kaya data keberadaan mushaf-mushaf dari khazanah lama yang tersimpan di berbagai penjuru dunia. Sayangnya, hanya beberapa yang mencantumkan nomor koleksi (museum) dan nomor panggil (perpustakaan). Keberadaan nomor koleksi pada deskripsi naskah merupakan kunci penghubung antara pembaca dan koleksi. Meskipun hanya berupa susunan beberapa angka, ia akan berguna, terutama jika ada pembaca yang hendak memperdalam, mengkaji, mengkritisi bahkan menikmati koleksi dimaksud.

Pada bagian akhir dari tiap ulasan mushaf, Aziz menggambarkan juga perkembangan percetakan mushaf di wilayah tersebut. Hanya saja, hal tersebut hanya dilakukan pada beberapa wilayah saja seperti Syiria, Mesir, Maroko, dan Iraq. Beberapa wilayah lainnya tidak ada keterangan tambahan tentang perkembangan mushaf cetak di daerah tersebut. Bahkan, wilayah Hijaz

${ }^{63}$ Zainal Arifin, “Diskursus Ulumul Qur'an Tentang Dabṭ Dan Rasm Usmani: Kritik Atas Tulisan 'Karakteristik Diakritik Mushaf Magribi, Arab Saudi Dan Indonesia,"” SUHUF 8, no. 2 (2015): 261-81. 
(Madinah) yang percetakan mushafnya terbesar di dunia, tidak diiuraikan Aziz. Ia hanya membahas sosok Usman Thoha dalam konteks penulis mushaf dari Syam yang mushafnya dicetak di Mujamma' Malik Fahd Madinah.

Latar belakang penulis sebagai peneliti yang berdomisili di Iraq cukup memengaruhi porsi kajian ini. Pembahasan sejarah khat mushaf Iraq lebih banyak dan luas dibandingkan bahasan mushaf wilayah lain. Selain itu, secara objektif, Iraq memang memiliki sejarah panjang dan pernah mewakili era kejayaan Islam masa Abbasiyah. Porsi terbanyak selanjutnya tentu yang terdekat dari Iraq yaitu Syam (Syiria), kemudian Iran, Mesir dan lainnya. Menilik kajiannya terhadap khat mushaf Timur tengah yang begitu luas dan mendalam, bisa jadi kajian Asia Dekat (Indonesia dan Cina) hanya pelengkap semata.

\section{PENUTUP}

Tidak ada salinan manuskrip yang jumlahnya lebih banyak dari pada teks Al-Qur'an. Ia disalin sejak dibukukan lima belas abad lampau hingga masa sekarang, baik dalam bentuk tulis tangan maupun melalui mesin cetak. Kajian terhadap naskahnya sudah banyak dan merentang waktu setidaknya dari masa daulah Umayyah, Abbasiyyah, era Fatimiyah dan Mamluk di Mesir, di Andalus, India, hingga masa sekarang. Dari sekian banyak kajian tersebut kebanyakan berkutat pada aspek bahasa, perbedaan qiraat, tanda wakof, pembagian juz (tahzzìb), dan tafsir. Selain itu ada juga kajian kaidah penulisannya (rasm) apakah sesuai dengan al-Dānī (w. 444 H) dalam kitab Muqni'nya; atau tentang tanda baca. Ada juga bahasan tentang rasm selain milik al-Dān̄̄ (w. $444 \mathrm{H}$ ) seperti milik al-Marākisyī ('Unwān al-Dālīl fì Marsūm Khat al-Tanzīl). Tidak ada naskah yang disalin dengan perhatian sangat besar di muka bumi sebagaimana dilakukan terhadap mushaf Al-Qur'an. Dari semuanya, tidak ketinggalan peran penting dari para khattat/kaligrafer Arab. Mereka melakukan penyempurnaan tulisan mushaf dari masa ke masa. Adanya Inovasi dalam bidang tulisan/khat mushaf menunjukkan bahwa orang yang melakukannya setara dengan pengkaji dari aspek ilmu-ilmu Al-Qur'an. 
Buku ini menegaskan bahwa kaligrafi benar-benar inti seni Islam (art of the Islamic art) ketika ia menjadikan Al-Qur'an sebagai inspirasi dan bentuk ekspresi. Ketika ia menyatu dengan Al-Qur'an maka kaligrafi mushaf juga memiliki sifat agung: selaras dengan ruang dan waktu. Al-Qur'an membawa kaligrafi ke model pertama dan utama bagi kreativitas dan produksi estetis, bahkan Ia memberikan material terpenting bagi kaligrafi Islam: ayat-ayat Al-Qur'an. Buku Aziz mengabarkan bahwa para kaligrafer Islam terkenal bukan semata karena tulisan indahnya, tetapi karena mereka menggunakan kaligrafi tersebut untuk menulis kalam Ilahi: Al-Qur'an Mulia.

Beberapa kekurangan pada buku ini, seperti terurai di atas, tidak mengurangi kualitas kajian-nya. Kekurangan tersebut menjadi peluang bagi penelitian mushaf lain untuk menambal dengan perspektif, data dan zonasi berbeda. Sebenarnya, andaikan buku ini membatasi kajian pada mushaf Timur Tengah saja sudah cukup memadai. Akan tetapi, kajian mushaf Timur Tengah saja belum komprehensif jika tidak mengkaji mushaf dunia Islam.

Berdasarkan analisis di atas, penulis memberikan dua rekomendasi. Pertama, untuk para peneliti khazanah khususnya mushaf Al-Qur'an, karena kajian ini termasuk lintas disiplin ilmu, maka harus ada elaborasi dari berbagai bidang kajian. Penelitian khazanah mushaf tidak bisa dilakukan semata oleh peneliti khazanah atau peneliti ilmu Al-Qur'an. Elaborasi guna mengungkap khazanah mushaf dari berbagai disiplin ilmu mutlak dilakukan. Kedua, untuk pemilik naskah mushaf baik individu lebih-lebih lembaga, hendaknya dapat membuka diri kepada para peneliti dengan tetap memerhatikan kelestarian naskah. Khazanah mushaf selain benda pusaka, ia sebenarnya berfungsi juga sebagai pustaka. 


\section{DAFTAR PUSTAKA}

\section{Buku}

al-Faruqi, Isma'il R. Atlas Budaya Islam: Menjelajah Khazanah Peradaban Gemilang. Edited by Ilyas Hasan. III. Bandung: Mizan, 2001.

al-Kurdi, Muhammad Țāhir bin 'Abdul Qādir. Tārīkh Al-Qur'ān Wa Gharā'ibu Rasmihi Wa Hukmuhu. Jeddah: al-Fath, 1946.

al-Muqrizi, Taqiyuddin Ahmad bin Ali. Al-Mawā'iz Wa AlI'tibār Bi Dzikri Al-Mawāqi’i Wa Al-Āsārr. kairo: Bulaq, n.d. al-Qazwaini, Zakariyyā bin Muhammad bin Mahmud. Āsār AlBilād Wa Akhbār Al-'Ibād. Beirut, 1979.

Blair, Sheila S. Islamic Calligraphy. Edinburgh: Edinburgh University Press, 2006.

Déroche, François. Qur'ans of the Umayyads: A First Oveerview. Edited by Léon Buskens. Leiden: Brill, 2014.

George, Alain. "The Qur'an, Calligraphy, and the Early Civilization of Islam." In A Companion to Islamic Art and Architecture, edited by Finbarr Barry Flood, 1st ed., 109-29. New Jersey: John Wiley \& Sons, 2017.

Ibnu Bațūṭah. Tuhfah An-Nadhār Fì Garā'ib Al-Amșār Wa 'Ājā'Ib Al-Asfār. Beirut, 1985.

Ibnu Jubair, Muhammad bin Ahmad. I'tibā Al-Nāsik F̄̄ Dzikri Al-Āsār Al-Karīmah Wa Al-Manāsik. Beirut, 1986.

Jackson, Peter. Dari Puncak Barbar, Penaklukan Mongol Ke Dunia Islah Hingga Menjadi Muslim. Edited by Fahmi Yamani. 1st ed. Jakarta: Serambi, 2019.

Ṣāliḥ, Abdu al-Azīz Hamīd. Khaṭ Al-Muṣhaf Al-Sharīf Wa Tațawwaruhu F̄̄ Al-'Ālam Al-Islāmì. Beirut: Dār al-Kutub alIlmiyyah, 2020.

Tjandrasasmita, Uka. Arkeologi Islam Nusantara. Jakarta: Kepustakaan Populer Gramedia, 2009. 


\section{Jurnal IImiah}

Akbar, Ali. "Mushaf Sultan Ternate Tertua Di Nusantara?: Menelaah Ulang Kolofon." Lektur 8, no. 2 (2010): 283-96.

Akbar, Faris Maulana. "Peranan Dan Kontribusi Islam Indonesia Pada Peradaban Global." JURNAL INDO-ISLAMIKA 10, no. 1 (2020): 51-63.

Arifin, Zainal. "Diskursus Ulumul Qur'an Tentang Dabț Dan Rasm Usmani: Kritik Atas Tulisan 'Karakteristik Diakritik Mushaf Magribi, Arab Saudi Dan Indonesia."” SUHUF 8, no. 2 (2015): 261-81.

Azra, Azyumardi. "Islam Indonesia: Kontribusi Pada Peradaban Global." Prisma 29, no. 4 (2010): 83-91.

Dutton, Yasin. "Qur'ans of the Umayyads: A First Overview." Journal of Qur'anic Studies 18, no. 1 (2016): 153-57.

"Two 'Hijāzī' Fragments of the Qur'an and Their Variants, or: When Did the Shawādhdh Become Shādhdh?" Journal of Islamic Manuscripts 8, no. (2017): 1-56.

Faizin, Nur. "Keraguan Seputar Mushaf Al-Qur'an: Kajian Resepsi Terhadap Manuskrip Birmingham." SUHUF 9, no. 2 (August 16, 2017): 215-40. https://doi.org/10.22548/shf. v9i2.241.

Hakim, Abdul. "Khazanah Al-Qur'an Kuno Bangkalan Madura: Telaah Atas Kolofon Naskah." SUHUF 8, no. 1 (2015): 2344.

"Metode Kajian Rasm, Qiraat, Wakaf Dan Dabt Pada Mushaf Kuno (Sebuah Pengantar)." SUHUF 11, no. 1 (August 24, 2018): 77-92. https://doi.org/10.22548/shf. v11i1.322.

Hidayatullah, Muhammad Syarif. "Teori-Teori Masuknya Islam Ke Wilayah Timur Indonesia." Jurnal Sivitas Akademika UI, (2014) 1-15.

Kurniawan, Hendra. "The Role of Chinese in Coming of Islam to Indonesia: Teaching Materials Development Based on 
Multiculturalism.” Paramita - Historical Studies Journal 27, no. 2 (2017): 238-48. https://doi.org/10.15294/ paramita. v27i2.8660.

Lipa, Ludgardis, Nurdin Hidayah, and Dendy Sundayana. "Pengembanan Fasilitas Interpretasi BErbasis QR Code MEnggunakan System Development Life Cycle (SDLC): Studi Kasus Di Museum Negeri Sri Baduga, Bandung." Barista: Jurnal Kajian Bahasa Dan Pariwisata 6, no. 2 (2019): 39-48. https://doi.org/10.34013/barista.v6i2.181.

Muñoz, Nuria Martínez-de-Castilla-. "Qur'anic Manuscripts from Late Muslim Spain: The Collection of Almonacid de La Sierra." Journal of Qur'anic Studies 16, no. 2 (2014): 89-138.

Nurkholisha, Ridha Anggi, and Lydia Christiani. "Evaluasi Kebijakan Pengembangan Koleksi Di Perpustakaan Nasional Republik Indonesia (Pnri) Pada Naskah Nusantara." Jurnal Ilmu Perpustakaan 7, no. 3 (2018): 81-90.

Rippin, A. "Qur'ans of the Umayyads." American Journal of Islam and Society 32, no. 4 (2015): 114-17.

Rosyad, Achmad Faizur. "Karakteristik Diakritik Mushaf Magribi, Arab Saudi, Dan Indonesia: Studi Perbandingan." SUHUF 8, no. 1 (2015): 69-90.

Sadeghi, Behnam dan Mohsen Goudarzi. "Sanaa 1 and The Origins of The Qur'an.” Der Islam 87, no. 1-2 (2012): 1129.

Saefullah, Asep. “Aspek Rasm, Tanda Baca Dan Kaligrafi Pada Mushaf-Mushaf Kuno Koleksi Bayt Al-Qur'an Dan Museum Istiqlal." SUHUF 1, no. 1 (2008): 87-110.

Sirojuddin A.R., Didin. "Peta Perkembangan Kaligrafi Islam Di Indonesia.” Al-Turās 20, no. 1 (2014): 219-231.

\section{Disertasi}

Akbar, Ali. "Naskah Qur'an Nusantara: Kajian Kaligrafi.” Disertasi pada Program Pascasarjana Universitas Indonesia, 2016. 